ISSN 2078-6077.

Наукові зошити історичного факультету Львівського університету. 2018-2019. Випуск 19-20. С. 467-480 Proceedings of History Faculty of Lviv University. 2018-2019. Issue 19-20. P. 467-480

УДК 930:[378.4.091.113А.Бек(477.83-25-074)”'1914/1918”(047.32)

\title{
АДОЛЬФ БЕК ПРО ЛЬВІВСЬКИЙ УНІВЕРСИТЕТ У ПЕРІОД ПЕРШОЇ СВІТОВОЇ ВІЙНИ
}

\author{
Володимир КАЧМАР \\ Львівський національий університет імені Івана Франка \\ кафедра новітньої історії України імені М. Грушевського \\ вул. Університетська, 1, Львів, 79000, Україна \\ e-mail:wkachmar13@gmail.com
}

\begin{abstract}
Йдеться про діяльність Львівського університету в період Першої світової війни. Зроблено акцент на аналізі спогадів ректора Університету Адольфа Бека про функціонування закладу вищої освіти, зокрема, його діяльність у 1914-1915 н. р.

Ключові слова: Львівський університет, Адольф Бек, Перша світова війна, російська окупація, факультети, накази, студенти.
\end{abstract}

Студії над історією Львівського національного університету ім. Івана Франка (далі Університету) з кожним роком все більше привертають увагу істориків. Важливою особливістю Університету - одного з найстаріших закладів вищої освіти в Україні $є$ те, що впродовж понад трьох століть він завжди перебував на перехресті науково-культурних зв' язків українського, польського, австрійського та інших европейських народів. Історію Львівського університету дослідники завжди розглядатимуть як невід'ємну частину вітчизняної та світової науки.

У минулому столітті вийшло чимало студій, пов'язаних із історією Університету. Головні видання були приурочені ювілейним датам з його історії. Увагу заслуговують публікації, що побачили світ напередодні Першої світової війни ${ }^{1}$. Радянський період залишив по собі декілька цікавих ювілейних видань ${ }^{2}$. У XXI ст. поштовхом до появи нових розвідок стало відзначення в Україні та за іiі межами ювілейної дати - 350-річчя від часу заснування Університету. Науковці Львівського університету зустріли ювілей фундаментальним виданням двотомовою “Енциклопедією Львівського університету”з. Мабуть, детальнішого та великосяжнішого видання з історії закладу вищої освіти в Україні до цього часу не було. У 2015 р. наші польські колеги презентували своє бачення історії Університету у Львові виданням, яке неоднозначно та доволі критично сприйняли

\footnotetext{
${ }^{1}$ Kronika Uniwersytetu Lwowskiego, T. 2 (1898-1910). Zestawil W.Hahn, (Lwów: Nakładem senatu akademickiego C.K. uniwersytetu Lwowskiego, 1912). 351; Jaworski, F. Uniwersytet Lwowski. Wspomnienie jubileuszowe. (Lwów: Nakładem towarzystwa milosników przesztoszci Lwowa, 1912), 88.

2 Львівський університет, 1661-1986. Ред. колегія В. П. Чугайов, С. А. Макарчук, Д. С. Григораш. (Львів: Вища школа, 1986), 144; Євген Лазаренко. 300 років Львівського університету. (Львів: Вид-во Львівського університету, 1961). 82.

${ }^{3}$ Encyclopedia. Львівський начіональний університет імені Івана Франка: в 2 т. Т. I: А-К (Львів: ЛНУ імені Івана Франка. 2011), 716.
} 
ISSN 2078-6077. Наукові зошити історичного факультету Львівського університету. 2018-2019. Випуск 19-20. Proceedings of History Faculty of Lviv University. 2018-2019. Issue 19-20.

львівські історики. Серед іншого, критика звучала щодо власної назви видання, яке ототожнює історію Університету винятково як надбання лише польського народу ${ }^{4}$.

Як відомо, історію Львівського університету в різні часи творили багато европейських науковців. Одним із найцікавіших етапів становлення Університету як европейського світського закладу вищої освіти, без сумніву, був його австрійський період - від 1784 до 1918 рр. Перебуваючи у складі австрійської держави, Університет став визначним осередком освіти, науки та культури. Австрія своїми культурними, економічними й освітніми можливостями відіграла надважливу роль для населення Західної України. Особливо для розвитку його освітнього та наукового потенціялу. Молодь одержала можливість здобувати якісну освіту не лише у Відні, а й власне у Львові, у тому числі - завдяки відкритому 1784 р. цісарем Йосифом II державному Університеті. Натомість галицькі українці за це завше були вдячні династії Габсбургів, під покровом якої перебували майже півтораста років. Про це свідчать слова Андрея Шептицького; 28 червня 1910 p. у його виступі в Палаті панів Віденського парламенту щодо справи українського університету. Митрополит зазначав: “Русини почувають се як добродійство Божого провидїня, що найшли в Австриї правдиву релїгійну толєранцию і забезпеку свободи до розвитку своєї культури"5.

Подаємо маловідому сторінку історії Львівського університету останніх років його перебування у складі Австрії - період окупації Львова російським військом у часи Першої світової війни. Дослідники тієї епохи відзначають, що найбільше під час війни постраждало населення етнічних українських територій, яке мешкало на території Австро-Угорщини. Військові дії, репресії російської окупаційної влади прирекли на страждання сотні тисяч людей 6 . Львівський університет, як і всі установи Львова, вимушений був функціонувати в той період відповідно до законів воєнного часу.

Серед ріжних джерел, які допомагають нам відобразити події, що відбувалися в Університеті в роки Першої світової війни, важливе місце займають документи, які зберігаються в Державному архіві Львівської області. Насамперед йдеться про фонд 26 (Львівський королівський університет імені Франца I). Зокрема, звіт про події в університеті за 1914-1915 рр. та листування з Галицьким намісництвом у Львові про евакуацію службовців зі Львова у 1915-1916 рр., про евакуацію документів Львівського Університету на час війни, про останні дні роботи в університеті, матеріяли щодо евакуації працівників та $\mathrm{iн}^{7}$. Однак

${ }^{4}$ Academia Militans. Uniwersytet Jana Kazimierza we Lwowie, red., wstęp i zakończenie Adam Redzik, Wydawnictwo Wysoki Zamek, Instytut Pamięci Narodowej, Kraków 2015, 1302.

${ }_{5}^{5}$ Промова митрополита гр. А. Шептицького в палаті вельмож 28 червня 1910 р., ЦДІА України у Львові, ф.206 (Рідна школа ), оп.1, спр.9, арк. 78.

${ }^{6}$ Велика війна 1914-1918 рр. і Україна. У двох книгах. Книга 1. Історичні нариси. (Київ ТОВ Видавництво КЛІО, 2014), . 12-13.

7 ДАЛО, ф.26, оп. 13, спр. 752, арк. 3-29. 
серед пласту матеріялів, які відображають цю тематику, увагу привернув унікальний документ, який вельми цікаво відтворює події, що відбулися в Університеті в роки Першої світової війни. Йдеться про доповідну записку професора, доктора Адольфа Бека ${ }^{8}$ в Міністерство освіти та віровизнань, де він описує події, що тривали у Львівському університеті в період російської окупації Львова впродовж 1914-1915 рр. Записка надіслана 30 грудня 1916 р. - власне гарячими слідами подій в Університеті. Мотиви, які спонукали автора написати доповідну записку, знаходимо відразу ж у перших рядках тексту проф. Бека: “... я охоче використовую нагоду, яка в мене з'явилася, щоб описати Імператорсько-королівському міністерству події в університеті під час ворожої окупації. Це матиме не лише історичну цінність. Теперішня світова війна своїми надзвичайними подіями створила ситуації, які на початку війни ніхто не міг передбачити; перед цивільним громадянином і чиновником постали безпосередньо до і під час російського вторгнення питання, для відповіді на які він не міг знайти аналогічних випадків як відправні точки. Тому, очевидно, немаловажну, так звану дидактичну цінність матиме ретроспективний аналіз того, чи вирішення відповідних питань, чи оцінка ситуацій, які склалися, іповедінка у них громадянина, а особливо державного діяча на керівній посаді, були правильні"9. Вочевидь записка була написана 3 метою висвітлити передусім обставини, за яких Адольф Бек узяв на себе відповідальність керувати

\footnotetext{
${ }^{8}$ Бек (Beck) Адольф (01.I.1863, м. Краків, Польща - VIII.1942, м. Львів) - фізіолог, д-р медицини (1890), габіліт. д-р (O ciśnieniu krwi w źylach, 1894), проф. (1897). Закінчив мед. ф-т Ягеллон. ун-ту (1890). У 1885-1889 демонстратор, 1889-92 асист. каф. фізіології і гістології Ягеллон. ун-ту; 1892-94 наук. стажування; 1894-95 викладав фізіологію тварин у Ягеллон. унті; 1895-97 надзвич. проф., від 1897 проф. каф. фізіології Львів. ун-ту; 1898-99 проводив дослідж. на зоол. станції в Неаполі; 1903/04 декан мед. ф-ту, 1912/13 ректор Львів. ун-ту; 1915 вивезений до Києва, 1916 повернувся до Львова і продовжив роботу у Львів. ун-ті як зав. каф. фізіології (до 1934). Трагічно загинув під час арешту гестапо. Наук. інтереси: фізіологія та електрофізіологія нервової системи, сенсорна фізіологія, історія фізіології; біоелектричні явища в центр. нервовій системі та сітківці ока, локалізація центрів у корі гол. мозку, смакові та больові відчуття; мав наук. контакти з багатьма фізіологами світу, брав участь у підготовці та роботі Міжнар. конгресу фізіологів (Відень, 1910). Бл. 850 наук. праць та 100 наук. доп., зокр., O pobudliwości różnych miejsc tego samego nerwu (Pam. AU. 1888. T. 15); Die Bestimmung der Lokalisation der Gehirn- und Ruckenmarksfunktionen vermittelst der elektrischen Erscheinungen (Zbl. Physiol. 1890); Dalsze badania zjawisk elektrycznych w korze mózgowej (Rozpr. AU. 1896. T. 32; z spólaut.); O dwukierunkowym przewodzeniu nerwów (Rozpr. AU. 1917. Т. 57). За ред. Б. і Н. Цибульського видано підручник Fizjologia czlowieka (Warszawa, 1915; 1924). Dr. honoris causa Львів. ун-ту (1934). Президент Львів. т-ва лікарів (1901), почес. чл. Т-ва лікарів Вільнюса, чл.-кор. Матем.-природ. відділу Пол. АН (1913); чл. Лікар. від-ня Пол. АН (з 1930).

Л-pa: Kronika ULw.; M. Р. Гжегоцький А. М. Гжегоцька Адольф Бек та його вкладу урозвиток експериментальної фізіології. Експерим. та клін. фізіологія. (Львів, 1995). Sł. biologów pol.; Śródka. Т. 1. [фото]; Wojtkiewicz-Rok; ДАЛО, ф. 26, оп. 5, спр. 84. (М. Клевець. Адольф БЕК (Beck), Encyclopedia. Львівський національний університет імені Івана Франка : в 2 m. T. I : A-К, 189.

${ }^{9}$ ДАЛО, ф. 26, оп. 13, спр. 873, арк. 2.
} 
ISSN 2078-6077. Наукові зошити історичного факультету Львівського університету. 2018-2019. Випуск 19-20. Proceedings of History Faculty of Lviv University. 2018-2019. Issue 19-20.

Університетом. Після відновлення діяльности закладу вищої освіти виникали питання до професора щодо його повноважень в період окупації, не всім сподобалась ініціятива Бека фактично оголосити себе ректором.

Сумніви викликали і щодо діяльности решти професорів, які з ріжних мотивів не евакуювалися, а залишилися на окупованій ворогом території. Якби не було, але вважаємо, що публікація такого документа стане доброю нагодою для дослідників цього періоду ознайомитися з цікавими фактами з історії Львівського університету ${ }^{10}$.

"Викладацька та педагогічна праця професора Бека заслуговує особливої уваги" - відзначає у своїй студії професор Оксана Заячківська ${ }^{11}$. "У складний історичний період Першої світової війни він був повторно призначений ректором і став університетським лідером, проявивши рідкісні дипломатичні здібності в екстремальних військових умовах. Гуртуючи зусилля наукових колег та усіх працівників, що не залишили Львів, для збереження унікального університетського майна для майбутніх поколінь, Бек вдало і дипломатично аргументував академічні потреби перед окупаційною владою. Про тяжкі дні Першої світової війни Адольф Бек у 1935 р. написав спогади, що стали своєрідним документальним щоденником подій, які тоді охопили університет. Його пам'ять чудово зберегла найменші деталі воєнного часу у Львові, тому книга є історичним раритетом не лише подій, що відбувадися в університеті, а й у цілій Галичині, i які тривалий час замовчувались або спотворювались радянською пропагандою"

Отож, ще за день до початку Першої світової війни командування львівської залоги повідомило ректора Львівського університету проф. Станіслава Стажинського про те, що приміщення Університету переходять під їхню юрисдикцію. Серед іншого, в листі йшлося, що університетські будівлі планують використовувати лише в допоміжних цілях. У листуванні між сторонами адміністрація Університету наголошувала на тому, що приміщення, які передають військовим, мало би використовуватися лише в санітарних цілях ${ }^{13}$. В той же день ректор Стажинський зібрав професорів та деканів, які були у Львові, i повідомив їм про заходи, які потрібно було здійснити персоналові Університету, щоб врятувати архів та захистити університетське майно. Як описує про це А. Бек “Всі цінні предмети і важливі акти були перенесені у підвальні приміщення

${ }^{10}$ Документ уперше було перекладено з німецької на українську мову та опубліковано 2013 р. Друге доповнене видання вийшло у 2016 р. Див.: Сторінки історії Львівського університету (за матеріалами німецькомовних документів):навч.-метод. посібник. - видання друге, перероблене і доповнене. Упоряд. В.М. Качмар, М.С. Смолій. (Львів: ЛНУ імені І. Франка, 2016), 210

${ }^{11}$ Оксана Заячківська, Світ Адольфа Бека очима Генрика Бека: цілкком неофіційно. (Львів: БаК, 2013), 25.

12 Там само.

${ }^{13}$ ДАЛО, ф. 26, оп. 13. Спр. 409, арк. 31. 
університетської будівлі з метою захисту під час можливого обстрілу міста"14. Сам ректор оголосив, що покидає Львів і пропонував це зробити своїм колегам.

Відтак 9 серпня розпочався наступ на Львів. Росіяни вважали Львів добре укріпленим і не сподівалися на швидку перемогу. Однак австрійська команда вирішила залишити Львів. Частина мешканців покинула місто разом із військовими. Президія міста виступила перед мешканцями Львова зі зверненням. У ньому йшлося про відступ австрійського війська, зокрема був і заклик до населення не чинити опору противникові, зберігати порядок та спокій ${ }^{15}$.

Дня 3-го вересня 1914p. російське військо без бою зайняло Львів. До Львова 3-го вересня 1914 р. вступили російські частини. Військова російська адміністрація розглядала себе як окупаційну владу і провадила заходи, щоб поступово перевести Східну Галичину до рівня російських губерній. Для керівницва областями Австро-Угорщини, зайнятими по праву війни, розроблено Тимчасове положення, яке затвердив Верховний Головнокомандувач. Згідно 3 Положенням, ліквідовувалися органи австрійської влади і формувалися владні структури російської адміністрації: воєнний генерал-губернатор, губернатори, градоначальники і начальники повітів ${ }^{16}$. Безпосередніми обов'язками російської адміністрації вважалися: організація місцевого управління, повідомлення населенню про вимоги війська, вчасний збір податків, забезпека порядку на місцях. Головне завдання - задовольнити потреби російської армії.

Відразу запроваджено жорстку військову цензуру. Серед іншого, заборонялося розміщати дані про воєнні операції, роботу російської влади, друк та поширення плакатів, оголошень, світлин без дозволу місцевої поліції. Публікувати друковані праці дозволялося лише із зазначенням прізвища видавця. Лише за дозволом військової адміністрації дозволялося організовувати концерти, лекції, вистави, а показ кінофільмів - лише після попереднього перегляду.

Минуло чотири дні окупації Львова. Біля входу до головної будівлі Університету виставлено військові пости. Вартові перепускали в будівлю винятково за перепустками. Така система перепусток функціонувала впродовж 3-го вересня 1914-15 лютого 1915 рр. Напередодні, дня 1 вересня А. Бек узяв керівництво Університетом на себе. У Львові, на той час, залишилося семеро осіб професорів Університету - членів Сенату. Усвідомлюючи всю нелегітимність такого колегіяльного органу навчального закладу, все ж, як відзначав проф. Бек, "ми вважали справою найвищої важливости, навіть рятівним моментом для університету, що російські органи, які, між іншим, як виявилося, дуже слабо орієнтувалися в організації нашої вищої школи, зустрінуть на чолі

\footnotetext{
${ }^{14}$ Сторінки історії Львівського університету (за матеріалами німецькомовних документів)..., 162.

${ }^{15}$ Odezwy i rozporzadzenia z czasów rosyjskej okupacij Lwowa 1914-1915. (Lwów, 1915), 9.

${ }^{16}$ В. Ботушанський. “Російські плани інкорпорації Буковини (1914-1916 pp.)”, Науковий вісник Чернівецького університету: Збірник наукових праць. Вип. 229-230: Iсторія. Політичні науки. Міжнародні відносини. (Чернівці, 2004), 26-30.
} 
ISSN 2078-6077. Наукові зошити історичного факультету Львівського університету. 2018-2019. Випуск 19-20. Proceedings of History Faculty of Lviv University. 2018-2019. Issue 19-20.

університету автономний орган, оскільки інакше могло б, напевно, відбутися призначення російського чиновника керувати університетом"17.

Більшість викладачів, що залишилися, не працювали, адже навчання як такого не було. Професорам дозволяли приймати докторські екзамени (ригорози), переважно в колишніх випускників ${ }^{18}$. Окремі викладачі медичного факультету були учасниками “санітарного комітету”, завданням якого була мінімізація інфекційних захворювань ${ }^{19}$. Частина професорів виїхали зі Львова до університетів інших держав. Відтак, у Львові залишилися 59 професорів і приват-доцентів ${ }^{20}$.

Бібліотека Університету була зачинена відповідно до наказу нової влади. Виняток становили професори і студенти, які складали докторські екзамени. Значна частина професорсько-викладацького складу переїхала до Відня, обравши тимчасовим виконавцем обов'язків ректора професора Казимира Твардовського.

У листопаді 1914 р. академічний сенат Львівського університету ухвалив зосередити увагу адміністрації на організації навчання на місцях для львівських студентів, які були евакуйовані до Австрії, Чехії. Міністерство освіти та віровизнань Австрії дозволило львівським професорам та студентам юридичного факультету складати державні і докторські іспити у Відні. Для малозабезпечених студентів сенат домігся, щоб влада виділила місця в гуртожитку.

Заняття у Львівському університеті відновили в 1915 р., після того, як австронімецькі війська опанували Львовом, а викладачі і частина студентів повернулися 3 Австрії. Загалом відновити навчальний процес було доволі складно. Причини були ріжні. Передусім відчувалась нестача персоналу, адже значна частина викладачів служила в австрійському війську, інша - перебувала в російському полоні ${ }^{21}$. Ще більше ситуація загострилася в листопаді 1915 р. - чимало професорів підтримали пропозицію Міністерства щодо роботи в новоутвореному Варшавському університеті ${ }^{22}$.

До слова, студенти були противниками таких переходів - у липні 1918 p. виступили перед ректоратом і академічним сенатом щодо протистояння масовим виїздам професорів до Варшави ${ }^{23}$. Станом на 1917-1918 рр. статистичні дані виглядали так: всього працівників - 156, з них професорів - 86, приват-доцентів 57 , суплент -1 , лекторів $-12^{24}$. Через важке матеріяльне становище більшости викладачів утворено університетську споживчу спілку, а згодом навіть відкрито спеціяльну продуктову крамницю ${ }^{25}$.

\footnotetext{
${ }^{17}$ Сторінки історії Львівського університету (за матеріалами німецькомовних документів): навч.-метод. посібник, видання друге, перероблене і доповнене. Упоряд. В. М. Качмар, М. С. Смолій. (Львів: ЛНУ імені І. Франка, 2016), 163.

${ }^{18}$ ДАЛО, ф.26, оп. 13, спр. 598, арк. 15.

${ }^{19}$ Там само, спр. 499, арк. 9.

${ }^{20}$ Там само, спр. 409, арк. 36.

${ }^{21}$ Там же, ф. 26, оп. 13, спр. 499, арк. 15-19, 23, спр. 504, арк. 20-21, спр. 543, арк. 28.

${ }^{22}$ Там же. Спр. 543, арк. 10-11, 28.

23 “Muzeumo, 1918, № 7: 355.

${ }^{24}$ Skład uniwersytetu Lwowskiego w roku akademickim 1917-1918, Lwów, 1917.

${ }^{25}$ ДАЛО, ф. 26, оп. 13, спр. 673, арк. 22, 56; спр. 674, арк. 7, 47.
} 
ISSN 2078-6077. Наукові зошити історичного факультету Львівського університету. 2018-2019. Випуск 19-20. Proceedings of History Faculty of Lviv University. 2018-2019. Issue 19-20.

Щодо кількости студентів у загаданий період, то в 1915-1916 н. р. їх навчалося 1206 осіб, у 1916-1917 н. p. -1259, у 1917-1918 н. p. -216826. Відтак, причиною зменшення кількости студентів у роки війни було передусім те, що випускників гімназій австрійська влада прикликала до військової служби. Власне тому тоді різко збільшилася кількість жінок на філософському та медичному факультетах. Національний склад студентів того часу виглядав так ${ }^{27}$ :

\begin{tabular}{|c|c|c|c|c|}
\hline $\begin{array}{c}\text { Навчальні } \\
\text { роки }\end{array}$ & \multicolumn{4}{|c|}{ Національний склад у \% } \\
\hline & українці & поляки & свреї & Інші \\
\hline $1915-1916$ & 24.8 & 50.9 & 23.1 & 1.2 \\
\hline $1916-1917$ & 24.6 & 48.4 & 26.0 & 1.0 \\
\hline $1917-1918$ & 23.2 & 41.2 & 34.1 & 1.5 \\
\hline
\end{tabular}

Аналізуючи дані таблиці, бачимо, що відсоток українців практично не змінювався. Натомість кількість поляків зменшувалася обернено-пропорційно до числа євреїв. Загалом ситуація щодо національного співвідношення студентів передвоєнного та воєнного періодів майже не відрізнялася.

Чимало тодішніх студентів перебували у важкому матеріяльному становищі. Відтак, у лютому 1918 р., австрійський уряд виділив для малозабезпечених студентів Львівського університету доброчинну грошову допомогу в розмірі 8000 корон (1610 корон дісталося студентам-українцям, 6390 корон - студентамполякам $)^{28}$.

Зазначимо, що після повернення австрійської влади до Львова лише окремі студентські організації відновили свою роботу. Серед них “Академічна громада", “Академічна читальня”, “Академічна поміч”, “Бібліотека слухачів права”, "Братня допомога слухачів університету"29.

“Заарештований російською комендатурою та відправлений на заслання, Адольф Бек вдруге в 1917 році став львів'янином, не дивлячись на воєнні страхіття, обстріли, пожежі, нестачу їжі, побутові незручності та важкі часи, які переживав Львів. У своєму улюбленому місті, за його власним визнанням, він провів 47 років свого життя, не залишаючи Львів навіть у тяжкі часи Другої світової війни" ${ }^{\prime \prime}$.

\footnotetext{
${ }^{26}$ Skład uniwersytetu Lwowskiego w roku akademickim. 1916-1917, Lwów, 1916: Skład ... w roku akademickim. 1917-1918, Lwów, 1917.

27 ДАЛО, ф. 26, оп. 4, спр. 180, арк. 115.

${ }^{28}$ Там же, ф. 26, оп. 13, спр. 674, арк. 6, 30.

${ }^{29}$ Там же, спр. 495, арк. 3-4, там же, спр. 674, арк. 47.

${ }^{30}$ Оксана Заячківська, Світ Адольфа Бека очима Генрика Бека: иілком неофічійно..., 25.
} 
ISSN 2078-6077. Наукові зошити історичного факультету Львівського університету. 2018-2019. Випуск 19-20. Proceedings of History Faculty of Lviv University. 2018-2019. Issue 19-20.

\section{Документ}

Доповідна записка проф. д-ра Адольфа Бека про події в університеті під час російської окупації 1914-1915 рр. ДАЛО, ф. 26, оп. 13, спр. 873, 15 арк.

\section{Доповідна записка \\ проф. д-ра Адольфа Бека про події в університеті під час російської окупації 1914-1915 рр. Львів, 30 грудня 1916 р. ІМПЕРАТОРСЬКО-КОРОЛІВСЬКЕ МІНІСТЕРСТВО!}

У тимчасовому звіті від 16 серпня 1915 р., № 265 ех 1914-1915, який надав ректор на 1914-1915 навчальний рік про процеси в тутешньому університеті під час російської окупації, він зазначив, що об'єктивний і вичерпний опис цих подій можна буде зробити лише після його повернення.

Оскільки я завдяки успішним старанням моїх колег і прихильности високого Імператорсько-королівського уряду відданий своїй Батьківщині та університетові, то я охоче використовую нагоду, яка у мене з'явилася, щоб описати Імператорсько-королівському міністерству події в університеті під час ворожої окупації. Це матиме не лише історичну цінність. Теперішня світова війна своїми надзвичайними подіями створила ситуації, які на початку війни ніхто не міг передбачити; перед цивільним громадянином і чиновником постали безпосередньо до і під час російського вторгнення питання, для відповіді на які він не міг знайти аналогічних випадків як відправні точки. Тому, очевидно, немаловажну, так звану дидактичну цінність матиме ретроспективний аналіз того, чи вирішення відповідних питань, чи оцінка ситуацій, які склалися, і поведінка у них громадянина, а особливо державного діяча на керівній посаді, були правильні.

Хронологічно історія важких десяти місяців така:

Дня 30 серпня 1914 р. після обіду ректор університету д-р Стажинський зібрав декількох зі старших професорів і деканів факультетів, які залишилися у Львові, на конференцію і повідомив зборам (на яких я, як професор, був присутній) про те, що він в цей же день одержав від Його Ясновельможности імператорськокоролівського намісника листа, де йдеться, що настав час перенести архіви i цінні предмети університету в надійне місце поза межами Львова. Отже, було ясно, що наша армія залишить місто і на нас чекає захоплення міста ворогом. Ректор заявив при цьому, що він залишить місто і порадив проректорові зробити те ж саме. Про порятунок архіву і майна університету не могло бути й мови через занадто короткий час, який залишився. Всі цінні предмети і важливі акти вже до того були перенесені у підвальні приміщення університетської будівлі 3 метою захисту під час можливого обстрілу міста.

Мотиви, які були вирішальними при виборі між втечею і залишенням для кожної окремої людини, ускладнювалися у ці фатальні важкі дні тією мірою, в 
якій від психічного стану кожного і безлічі зовнішніх обставив залежало те, чи пізніше навряд чи хтось із тих, хто залишився, із впевненістю зможе сказати про себе, що він зробив це при повному усвідомленні подій, які на нього очікують, у цілковитій переконаності в тому, що він виконає свій обов'язок, якщо не залишить довірений йому пост. Отже, і я не хочу вважати своєю заслугою той факт, що я після двох жахливих днів нерішучости, проведених у важкій душевній боротьбі, прийняв рішення залишитися. Пізніше я переконався, що я вчинив на користь і благо університету.

Відтак 1 вересня 1914 р. за відсутности ректора я взяв на себе керівництво університетом і дав службовому персоналові і слугам відповідні розпорядження.

У перші три тижні після вторгнення ворожих військ ані військові, ні цивільні органи не турбували університет. Не появився ніхто (як і треба було очікувати), щоб оглянути або зайняти університет. У цей час я провів декілька нарад 3 членами тодішнього академічного сенату, які залишилися у Львові, до яких були залучені авторитетні колеги, такі, як придворний радник проф. Дембінський, придворний радник проф. Фінкель, проф. І. Закшевський і частково також почесний професор Його Ясновельможність граф Пінінський. Насамперед ухвалено, що й після 23 вересня 1914 р., поки обставини не зміняться, вибраний на 1913-1914 навчальний рік академічний сенат університету повинен керувати справами університету. Присутніми були 7 членів цього сенату (проректор Бек, декани: Гертсманн, Юраш, заступники деканів Кучера і Гадачек, засідателі Серадзький і Станіслав Закшевський); ми зарахували до академічного сенату ще проф. Хлямтача, оскільки він також під час канікул виконував обов'язки декана юридичного факультету і цю функцію виконував протягом цілого року окупації.

Ми, звичайно, усвідомлювали той факт, що легальність цього академічного сенату може бути поставлена під сумнів, проте ми вважали справою найвищої важливости, навіть рятівним моментом для університету, що російські органи, які, між іншим, як виявилося, дуже слабо орієнтувалися в організації нашої вищої школи, зустрінуть на чолі університету автономний орган, оскільки інакше могло б, напевно, відбутися призначення російського чиновника керувати університетом. Я повинен особливо наголосити на тому, що ініціятива прийняття такої ухвали походила від мене самого, і я хочу нести повну відповідальність за цей крок, за який академічному сенатові на початку з боку декого були зроблені деякі закиди.

Після цього ми вирішили дати розпорядження відкрити вогнетривкий сейф каси скарбниці, до якої не було в наявності ключів, і використати готівку, яка там була, для авансової підтримки службовців і слуг, які залишилися.

На цей час припадають також заходи, які я розпорядився провести у всіх приміщеннях тутешніх академічних товариств. Російське командування міста під загрозою смертельної кари наказало видати всю зброю; незабаром мали би відбутися обшуки (також у залишених будинках). Тому за допомогою так званої 
ISSN 2078-6077. Наукові зошити історичного факультету Львівського університету. 2018-2019. Випуск 19-20. Proceedings of History Faculty of Lviv University. 2018-2019. Issue 19-20.

громадської охорони я розпорядився відкрити відповідні приміщення товариств і забрати все, що з боку росіян могло б викликати переслідування, - там зберігалися, наприклад, уніформа й елементи спорядження для легіонерів і т. ін. Два будинки фондів: Дім академічний імени Адама Міцкевича і Дім академічний імени Андрія Потоцького, які, звичайно, стояли порожніми, були - для того, щоб їх не захопив ворог, - використані для гуманітарних цілей: один для будинку сиріт, а другий для будинку інвалідів.

Управлінські акти ректора, а також інші важливі документи, цінні медалі і т. ін. були запаковані i, скріплені приватною печаткою, здані до банку на зберігання 3 написом “Цінні папери” як приватна власність.

Відтак 25 вересня 1914 р. в університеті з'явився делегат генералгубернатора, депутат думи Чіхачов, у супроводі приват-доцента нашого університету Івана Добрянського, котрий повинен був виконувати роль перекладача. Згодом виявилося, що обмін думками через перекладача дуже ускладнюється, і тому від того часу в особистому спілкуванні з паном Чіхачовим я користувався завжди французькою мовою.

Пан Добрянський заявив, що делегат хоче тільки оглянути університет і лише одержати інформацію про його заклади, але не займати його. Через декілька днів пізніше він підтвердив, що російські органи на цей час не думають оволодіти університетом, але вони проте не мають наміру дозволити відкрити навчальний рік і проводити лекції. Детальний огляд головної будівлі, університетської бібліотеки, інститутів і деяких клінік зайняв 2 дні.

Дня 2 жовтня 1914 р. мене викликав генерал-губернатор Бобринський. Він повідомив мені (французькою мовою), що він залишає мене на чолі університету як його керівника, причому він призначив мене особисто відповідальним за все майно університету, бібліотеки, інститутів. Він хотів мені, за необхідности, надати охорону. У моєму зверненні (французькою мовою) я попросив генералагубернатора про дбайливе ставлення до університету. Покладену на мене відповідальність я мусив і хотів, звичайно, прийняти.

$[\ldots]$

Незабаром після цього я видав керівникам семінарів і правлінням інститутів, які залишилися у Львові, циркуляр, у якому звернув їхню увагу на важку відповідальність, яка на мене покладена, і попросив їх взяти під своє заступництво інститути, які перебували під їхнім керівництвом, або збірки, що було необхідним за тих обставин. Нагляд над тими інститутами, керівництво яких було відсутнє, взяли на себе на моє прохання інші колеги тих правлінь або асистенти інститутів.

Від генерал-губернатора я спочатку не одержав жодного письмового документа про функції, які на мене були покладені під час тої авдієнції. Лише коли 9 жовтня 1914 р. мене за наказом начальника міста арештували і потім затримували як заручника, і коли я, протестуючи проти цього, наголосив на тому, що, будучи арештованим, я не зможу тоді керувати справами університету i 
нести покладену на мене відповідальність, і коли мене за розпорядженням генерал-губернатора випустили на волю, під час наступної зустрічі з паном Чіхачовим (у листопаді) я вимагав, щоб мені видали відповідний документ, який зміг би захистити мене в майбутньому від такого роду знущань з боку поліції. Такий документ я одержав у кінці листопада. Я носив його завжди з собою і взяв також у полон в Росію, де він мені добре прислужився, оскільки деякою мірою захистив мене від сваволі тамтешніх чиновників.

Ставлення ректорату до генерал-губернатора було одночасно стриманим i коректним. Я уникав того, щоб звертатися з будь-якими проханнями до генералгубернатора або до його канцелярії. Якщо ж я був вимушений давати письмову відповідь на листи, які приходили з канцелярії генерал-губернатора, то це відбувалося постійно у формі листа, складеного французькою мовою, який я особисто скеровував і адресував панові Чіхачову.

$[\ldots]$

До конфліктів із російськими органами не доходило. Ректорат мусив уникати цього $з$ максимальною педантичністю, оскільки можна було припустити, що найменший опір офіційним розпорядженням може наразити на найбільшу небезпеку не тільки того, хто підписався, а й також, що було набагато важливіше, могло заподіяти шкоду університетові.

Поліцейські органи вимагали від усіх власників будинків вивішувати прапори у так звані урочисті дні. Поліція і поліцейські чиновники ходили від будинку до будинку і погрожували великими штрафами на випадок непокори. Університетська будівля не могла бути винятком. Проте в день після падіння фортеці у Перемишлі (23 березня 1915 р.) - один із найважчих і найтрагічніших днів, які ми провели у ті місяці жаху, - ректорат не захотів підкорятися наказові. Ні на головній будівлі, ні на бібліотеці чи іншій будівлі університету не були вивішені прапори. На щастя, це не мало жодних неприємних наслідків.

Дня 16 січня 1915 р. поліцейський ревізор дав університетському педелеві усний наказ зняти австрійського імперського орла зі стіни університетської будівлі, а також всі зовнішні державні символи з будівель, які належать університетові. Коли я цілком проігнорував цей, даний таким своєрідним способом, наказ, поліцейський ревізор погрозив, що заарештує педеля і всіх слуг, якщо орла не буде знято зі стіни протягом 24 годин. Я негайно скерував протест приставові (комісарові) відповідного району, після цього - начальникові міста, що мало своїм наслідком щонайменше лише відстрочення, але як мінімум призвело до того, що ректорат одержав 15 лютого 1915 р. від начальника міста відповідне письмове розпорядження щодо цього. Я ще вагався, чи виконувати його, i намагався при посередництві пана президента Рутовського домогтися в генералгубернатора скасувати наказ (який походив від самого генерал-губернатора). Єдине, що вдалося, це тільки щодо символів, виготовлених в камені або на штукатурці. Всі відзнаки з бляхи і дерева слід було неодмінно видалити. Я не вважав за доцільне, щоб залучати університетських слуг, які зараховані на посаду 
ISSN 2078-6077. Наукові зошити історичного факультету Львівського університету. 2018-2019. Випуск 19-20. Proceedings of History Faculty of Lviv University. 2018-2019. Issue 19-20.

державою, виконувати той наказ. Тому я звернувся з клопотанням до президії міста, щоб вона послала декількох людей з міської пожежної охорони, які знімуть орла (виготовленого з бляхи) з фасаду головної будівлі університету, а ми зберегли його на кращі часи. (Орла поставили знову негайно на своє попереднє місце після відходу ворога).

$[\ldots]$

Серед університетських закладів особливий інтерес росіян викликала бібліотека. Пан Чіхачов відвідував ії декілька разів у супроводі ріжних російських високопоставлених осіб і політиків (серед них голова думи Родзянко, численні депутати думи), в яких справжнє захоплення викликали будівля, їі внутрішній інтер'єр, книжковий фонд. Про кожен такий візит мене повідомляли листом перед тим, звичайно, пізно вночі, яка цьому передувала. Спочатку прибуття солдата в нічний час викликало, безперечно, легко зрозуміле хвилювання і страх у моїй сім’ї. Поступово ми звикли до цих “безневинних” візитів.

Найбільше занепокоєння викликало в мене - принаймні у перші місяці окупації - скрутне матеріяльне становище професорів, персоналу службовців і слуг. Залишилися, крім 9 осіб персоналу канцелярії, 54 слуги із сім’ями і 29 сімей слуг, які перебували на військовій службі, і тому були відсутні.

$[\ldots]$

Другим болючим пунктом нашого господарства була нестача палива. Хоч у головній будівлі університету містився достатній запас дров, але незабаром його реквізували і мали вивезти. Завдяки нашим надзвичайним зусиллям нам вдалося нарешті звільнити від реквізиції частину дров для нас.

$[\ldots]$

Залишені квартири університетських професорів були під загрозою грабунку. На прохання і пропозицію ректорату імператорсько-королівський районний суд призначив із середовища присутніх професорів і персоналу службовців кураторів для кожної окремої квартири, які повинні були захищати майно відсутніх від знищення. Наскільки мені відомо, жодній із вказаних квартир не було нанесено якоїсь шкоди, за винятком квартири проф. д-ра Ст. Вітковського.

В останні тижні окупації серед жителів Львова панував жах. Росіяни схоплювали чоловіче населення на вулицях і примушували його до земляних робіт у воєнних цілях. Також декількох університетських слуг не оминула ця доля. Ректорат видав кожному службовцеві документ, у якому зазначено, що присутність відповідної особи в університеті або інституті безумовно необхідна. Це також допомагало в деяких випадках.

$[\ldots]$

Уже в кінці 1915 р. стало відомо, що росіяни на випадок евакуації Львова мають намір взяти заручників. Деякі з колег вважали у зв' язку з цим, що вони в небезпеці; я сам також побоювався за свою особу через можливий вивіз як заручника. 19 червня я дізнався від, як здавалося, добре поінформованої особи, 
що у списку заручників немає жодного університетського професора. Цю "радісну” звістку я повідомив також негайно колегам.

Через декілька годин мене і професора Дуніковського заарештували i наступного дня вивезли із 36 іншими, взятими як заручники, особами до Росії.

\title{
ADOLF BECK'S OPINION CONCERNING THE ACTIVITY OF LVIV UNIVERSITY DURING THE FIRST WORLD WAR
}

\author{
Volodymyr KACHMAR \\ Ivan Franko National University of Lviv \\ Department of Contemporary History of Ukraine \\ 1 Universytetska str., Lviv 79000, Ukraine \\ e-mail:wkachmar13@gmail.com
}

The article is about Adolf Beck's opinion concerning activities of the University of Lviv during the First World War. The emphasis is placed on the analysis of the memoirs of Adolf Beck, the rector of the University, on the functioning of this institution of higher education, in particular, its activities in 1914-1915.

The study of the history of Ivan Franko National University of Lviv (hereinafter referred to as the University) is increasingly attracting the attention of historians every year. An important feature of the University, one of the oldest institutions of higher education in Ukraine, is that over the course of more than three centuries, it has always been at the crossroads of scientific and cultural ties between Ukrainian, Polish, Austrian and other European nations. The history of Lviv University will always be regarded by researchers as an integral part of domestic and world science.

In the last century a lot of researches related to the history of the University came out. The main editions were confined to the anniversary dates of the history of Lviv University. In the twenty-first century, in Ukraine and abroad, there was the celebration of the jubilee date - the 350th anniversary of the foundation of the University. Scientists of Lviv University met the jubilee with the fundamental edition - the two-volume Encyclopedia of Lviv University.

The article covers the little-known page of the history of Lviv University in last years of its being in Austria - the period of the occupation of Lviv by Russian troops during the First World War.

Among the range of materials that reflect this subject, the attention is attracted to an exciting document that is very interesting and reproduces the events that took place at the University during the First World War. It is the memorandum by Professor Dr. Adolf Beck.

The document was written to highlight primarily the circumstances in which Adolf Beck assumed leadership of the University. After the restoration of the institution of higher education, there were questions to the professor about his powers during the occupation, not everyone liked Beck's initiative to actually declare himself a Rector.

The article contains the basic document, which demonstrates the attitude of Professor Dr. Adolf Beck to the activity of the University during the World War I and the time of Russian occupation in particular.

Keywords: Lviv University, Adolf Beck, First World War, Russian occupation, faculties, orders, students. 
ISSN 2078-6077. Наукові зошити історичного факультету Львівського університету. 2018-2019. Випуск 19-20. Proceedings of History Faculty of Lviv University. 2018-2019. Issue 19-20.

\section{REFERENCES}

Kronika Uniwersytetu Lwowskiego, edited by W.Hahn. Lwow: Nakladem senatu akademickiego C.K. uniwersytetu Lwowskiego, 1912. T. 2.

Jaworski F. Uniwersytet Lwowski. Wspomnienie jubileuszowe. Lwow: Nakadem towarzytwa milonikw przesztozci Lwowa, 1912.

L'vivs'kyy universytet, 1661-1986 edited by V.P. Chuhayov, S.A. Makarchuk, D.S. Hryhorash. L'viv: Vyshcha shkola, 1986.

Lazarenko YE. K. 300 rokiv L'vivs'koho universytetu. L'viv: Vyd-vo L'vivs'koho universytetu, 1961.

Encyclopedia. L'vivs'kyy natsional'nyy universytet imeni Ivana Franka. T. I, edited by I. O. Vakarchuk (holova), M. V. Lozyns'kyy, R. M. Shust, V. M. Kachmar. L’viv: LNU imeni Ivana Franka, 2011.

Academia Militans. Uniwersytet Jana Kazimierza we Lwowie, edited by Adam Redzik. Kraków: Wydawnictwo Wysoki Zamek, Instytut Pamięci Narodowej, 2015.

Promova mytropolyta hr. A. Sheptyts'koho v palati vel'mozh 28 chervnya 1910, Ruslan, No. 134 (1910).

TsDIA Ukrayiny u L'vovi, F.206 ( Ridna shkola ), Op.1, Spr.9, Ark.78.

Velyka viyna 1914-1918 rr. i Ukrayina, Knyha 1. Istorychni narysy. Kyiv: TOV "Vydavnytstvo "KLIO", 2014.

DALO, F. 26, op. 13, Spr. 752, Ark. 3-29.

Zayachkivs'ka Oksana. Svit Adol'fa Beka ochyma Henryka Beka: tsilkom neofitsiyno. L'viv: $\mathrm{BaK}, 2013$.

DALO, F. 26, Op. 13. Spr. 409, Ark. 31.

Odezwy i rozporzadzenia z czasow rosyjskej okupacij Lwowa 1914-1915. Lwow, 1915.

Botushans'kyy V. Rosiys'ki plany inkorporatsiyi Bukovyny (1914-1916 rr.) in Nauk, visn. Chernivets. un-tu: Zb. nauk, prats', Vyp. 229-230: Istoriya. Politychni nauky. Mizhnarodni vidnosyny, 2004.

Storinky istoriyi L'vivs'koho universytetu (za materialamy nimets'komovnykh dokumentiv): navch.-metod. posibnyk. Vydannya druhe, pereroblene i dopovnene, edited by. V. M. Kachmar, M.S. Smoliy, L'viv: LNU imeni I.Franka, 2016.

DALO, F.26, Op. 13, Spr. 598, Ark. 15.

"Muzeum", No. 7,(1918).

Sklad uniwersytetu Lwowskiego w roku akademickim. 1917-1918, Lwow, 1917.

DALO, F. 26, Op. 13, Spr. 673, Ark. 22, 56.

DALO, F. 26, Op. 13, Spr. 674, Ark. 7, 47.

DALO, F. 26, Op. 4, Spr. 180, Ark. 115. 